\title{
PERJANJIAN BAKU DALAM JUAL BELI KREDIT SEPEDA MOTOR DITINJAU DARI UNDANG-UNDANG NOMOR 8 TAHUN 19991
}

\author{
Oleh : \\ Anak Agung Adi Lestari ${ }^{2}$
}

\begin{abstract}
The title of this legal writing is standard agreemant in motorcycle sale-purchase credit based on Law No. 8 of 1999. This writing has a background on the development of technologies that helps humans more easily to fulfill the porpuse in their lives. This is about transportations means of motorcycle. The various types of vehicles to be marketed provide a portion of the position in the agreemant. One of the agreements can be seen in the field of motorcycle sale-purchases credit which become increasingly importantand a agreement is needed so that there is a legal certainty for the purchas. In a sale-pruchase agreement, there is a standard agreemant often used by business people to make a profit. In this case the party much involved with accountability is the consumer, i.e as and user of goods and services has a powerless position against the standard agreement given by the business people. In this case the business propietors are given the operating restriction and liability for losses suffered by consumers which are poured into the prevailing legislations. The method in this study used empirical methods. The legal protection on consumers in motorcycle sale-purchase credits is guided by the Law No. 8 of 1999, which regulates the rights and obligations of consumers and business people. The application of standard agreements in motorcycle sale-purchase credit must be in accordance with the Consumer Protection Act.
\end{abstract}

Keywords : Sale-pruchase agreement, Standard agreement, Consumer Protection

\begin{abstract}
Abstrak
Adapun judul penulisan hukum ini adalah perjanjian baku dalam jual beli kredit sepeda motor ditinjau dari Undang-Undang Nomor 8 Tahun 1999. Penulisan ini memiliki latar mengenai perkembangan teknologi yang telah manusia semakin mudah memenuhi tujuannya dalam hidupnya. Hal ini mengenai alat transportasi sepeda motor. Adanya jenis-jenis kendaraan yang beraneka ragam dipasarkan, hal tersebut akan memberikan porsi kedudukan dalam perjanjian. Salah satu perjanjian dapat dilihat pada bidang jual beli kredit terhadap transportasi kendaraan sepeda motor semakin penting artinya suatu perjanjian diperlukan agar terdapat kepastian hukum terhadap jual beli. Dalam suatu perjanjian jual beli dikenal adanya perjanjian baku yang sering dipergunakan oleh pelaku usaha

I Artikel ini merupakan karya ilmiah mahasiswa pada Program Studi Magister (S2) Ilmu Hukum Program Pascasarjana Universitas Udayana, serta mengucapkan terimakasih kepada Prof. Dr. Yohanes Usfunan, Drs.,SH.,M.Hum dan Dr. I Nyoman Suyatna, SH.,MH selaku Pembimbing Tesis.

2 Mahasiswa Program Magister (S2) Ilmu Hukum Universitas Udayana, Denpasar, Bali. Email: gungmirah118@gmail.com
\end{abstract}


untuk memperoleh keuntungan. Hal ini pihak yang banyak terlibat dengan pertanggung jawaban adalah konsumen, yaitu sebagai pemakai terakhir barang dan jasa mempunyai kedudukan yang tidak berdaya menghadapi perjanjian baku yang di berikan oleh pengusaha. Dalam hal ini para pelaku usaha diberikan batasan serta tanggung jawab atas kerugian yang dialami oleh konsumen yang dituangkan kedalam peraturan perundang-undangan yang berlaku. Adapun metode pada penelitian hukum ini menggunakan metode empiris. Perlindungan hukum terhadap konsumen dalam jual beli kredit sepeda motor berpedoman pada Undang-Undang Nomor 8 Tahun 1999, yang mengatur tentang hak dan kewajiban konsumen dan pelaku usaha. Penerapan perjanjian baku dalam jual beli kredit sepeda motor harus sesuai dengan Undang-Undang Perlindungan konsumen.

Kata Kunci : Perjanjian Jual Beli, Perjanjian Baku, Perlindungan Konsumen.

\section{PENDAHULUAN}

\subsection{Latar Belakang}

Dewasa ini perkembangan teknologi telah membuat manusia semakin mudah memenuhi beberapa tujuan dalam hidupnya. Seperti dalam adanya berbagai jenis kendaraan yang hampir setiap saat ada yang baru, baik dari teknologi maupun mereka dan lain-lain, sehingga warga masyarakat selalu ingin melihat barang-barang baru tersebut yang diyakini akan dapat memberikan service lebih baik dibandingkan dengan miliknya terdahulu. Adanya jenis-jenis kendaraan yang beraneka ragam dipasaran, hal tersebut akan memberikan porsi kedudukan dalam suatu perjanjian, perjanjian menurut Subekti adalah suatu peristiwa dimana seseorang berjanjiuntuk melaksanakan sesuatu hal. ${ }^{3}$

Uraian tersebut mengatakan, bahwa perjanjian merupakan dimana dua orang yang saling berjanjian untuk melakukan sesuatu dan mereka

Subekti, 1979, Hukum Perjanjian, Cet ke-IV, PT Intermasa, Jakarta, hlm 1. sama-sama mengadakan kesepakatan. Salah satu perjanjian dapat dilihat pada bidang jual beli kredit terhadap transportasi kendaraan sepeda motor semakin penting artinya suatu perjanjian diperlukan agar terdapat kepastian hukum terhadap jual beli.

Dalam suatu perjanjian jual beli dikenal adanya perjanjian baku yang sering dipergunakan oleh para pelaku usaha untuk memperoleh keuntungankeuntungan suatu target bisnisnya. Beberapa faktor penyebab terjadinya perjanjian baku oleh pelaku usaha adalah :

1. Adanya kebutuhan dari pengusahauntuk mempersiapkan isi perjanjian terlebih dahulu agar memudahkan penyediaan setiap saat, apabila masyarakat (konsumen) membutuhkan.

2. Pengusaha mengikut sertakan perjanjian baku dengan maksud untuk mengatur tanggung jawabnya jika pelaksanaan (prestasi) perjanjian itu tidak tercapai. 
Penerapan perjanjian baku adalah :

1. Dapat menghemat waktu pada setiap kali diadakan perjanjian, karena perjanjian baku adalah bersifat penawaran umum, dimana konsumen alternatifnya hanya tinggal menerima atau menolak sama sekali. Oleh sebab itu dengan adanya perjanjian baku itu tidak lagi diadakan perundingan-perundingan mengenai ketentuan-ketentuan kontrak, sehingga pembuatan perjanjian itu dapat berjalan cepat.

2. Dapat menghemat penggunaan tenaga dengan tidak lagi diadakan perundingan tentang ketentuan kontrak, maka berarti penyederhanaan pembuatan perjanjian, sehingga pengusaha dapat menyerahkan pekerjaan itu kepada orang-orang yang ada dibawah perintahnya.

3. Dapat menghemat pengeluaran untuk ganti rugi. Mengingat didalam perjanjian baku telah ditentukan tanggungjawabdalam hal mengganti kerugian, maka dengan pembakuan tersebut pengusaha akan memperoleh pembakuan, pengusaha akan memperoleh efisiensi dalam penggantian kerugian.

Pihak yang banyak terlibat dengan pertanggung jawaban adalah konsumen, yaitu pemakai terakhir dari barang dan jasa. Konsumen sebagai pemakai terakhir dari barang-barang dan jasa, mempunyai kedudukan yang tidak berdaya menghadapi perjanjian baku yang diberikan oleh pengusaha. Sehubungan dengan dengan penerapan perjanjianbakudalamsuatuperusahaan, dikenal adanya suatu klausula yang disebut "Exemption Clause" atau klause eksonerasi, yaitu berkaitan dengan pembatasan tanggung jawab dari pelaku usaha terhadap kerugian konsumen. ${ }^{4}$

Menurut uraian tersebut dapat dikatakan, bahwa para pelaku usaha diberikan batasan serta tanggung jawab atas kerugian yang dialami oleh konsumen yang dituangkan kedalam peraturan perundang-undangan yang berlaku. Dalam hal ini konsumen diharapkan mendapatkan pelayanan yang baik dari pelaku usaha dalam melakukan suatu transaksi jual beli. Jual beli merupakan suatu penerapan bisnis yang harus sesuai dengan peraturan dan memiliki suatu etika yang bertujuan supaya terciptanya praktek bisnis yang sehat dan beretika. Dengan menjalankan suatu perjanjian jual yang sehat serta sesuai dengan aturan dan memiliki suat etika yang baik, maka akan terjadi penerapan bisnis jual beli menjadi lancar sesuai dengan yang di harapkan warga masyarakat.

\footnotetext{
4 Mariam Darus Badrulzaman, 1981, Pembentukan Hukum Nasional Dan Permasalahannya, Alumni Bandung, hlm 68.
} 


\subsection{Perumusan Masalah}

Adapun masalah yang dibahas dalam penelitian berdasarkan latar belakang di atas, sebagai berikut:

1. Bagaimanakah perlindungan hukum terhadap konsumen atau debitur dalam jual beli kredit sepeda motor ditinjau dari Undang-Undang Nomor 8 Tahun 1999 ?

2. Bagaimanakah penerapan perjanjian baku dalam jual beli kredit sepeda motor ditinjau dari Undang-Undang Nomor 8 Tahun 1999 ?

\subsection{Tujuan Penelitian}

Penelitian ini memiliki tujuan adalah sebagai berikut:

\subsubsection{Tujuan Umum}

Secara umm penelitian ini memiliki tujuan untuk melatih diri dalam rangka menyatakan pikiran ilmiah secara tertulis dan untuk mengembangkan ilmu hukum terkait dengan paradigma science as a proces (ilmu sebagai proses). Dengan paradigma ini ilmu tidak akan pernah mandek (final) dalam penggaliannya atas kebenaran dibidang objeknya masing-masing. ${ }^{5}$

\subsubsection{Tujuan Khusus}

Secara khusus penelitian ini memiliki tujuan sebagai berikut:

Program Studi Magister (S2) Ilmu Hukum Program Pasca Sarjana Universitas Udayana, 2013, Pedoman Penulisan Usulan Penelitian Tesis dan Penulisan Program Studi Magister (S2) Ilmu Hukum, Denpasar, hlm 28.
1. Untuk mengetahui lebih mendalam sah atau tidaknya perjanjian baku tersebut, baik secara teoritis maupun dalam kenyataannya terhadap masyarakat dalam jual beli.

2. Untuk mengetahui penerapan perjanjian baku dalam jual beli kredit sepeda motor ditinjau dari Undang -Undang Nomor 8 Tahun 1999.

\section{METODE PENELITIAN}

Adapun metode yang dipergunakan dalam penelitian ini adalah metode empiris yan merupakan salah satu jenis penelitian hukum dimana menganalisis dan mengkaji bekerjanya di masyarakat. ${ }^{6}$ Penelitian secara empiris dimana bekerjanya hukum dalam masyarakat dikaji dari tingkat efektivitas hukum, dalam hal ini mengenai suatu perjanjian baku yang digunakan dalam jual beli sepeda motor.

Sumber data yang di pergunakan untuk mendukung penelitian ini bersumber yaitu:

1. Data primer

Data yang merupakan data yang diperoleh dari lokasi penelitian pada perusahaan sepeda motor. Diantaranya adalah perusahaan Suzuki Indo Perkasa sepeda motor beralamat di jalan Veteran No. 4 Denpasar, Yamaha Niaga Motor beralamat di

\footnotetext{
H.Salim dan Erlies Septiana Nurbani, 2013, Penerapan Teori Hukum Pada Penelitian Tesis dan Disertasi, PT Raja Grafindo Persada, Jakarta, hlm. 20.
} 
jalan Patimura No. 8 Denpasar, dan Made Ferry Motor beralamat di Jalan Patimura No. 24 Denpasar.

2. Data Sekunder

Data yang diperoleh dengan melakukan penelitian pada perpustakaan dengan mengkaji peraturan perundang-undangan yang mengatur perjanjian baku serta buku-buku hasil penelitian dari para ahli hukum dan jurnal-jurnal yang berkaitan dengan perjanjian baku.

\section{HASIL DAN PEMBAHASAN \\ 3.1 Perjanjian Baku Dan Perlindungan Konsumen}

Perjanjian baku merupakan standard contract yang dikemukakan oleh Az. Nasution dalam bukunya "Konsumen dan Hukum", 7 sedangkan dalam hukum Inggris menyebutkan sebagai Standard Form Contrat. Dalam hal ini, Abdulkadir Muhamad, menerjemahkan dengan istilah perjanjian baku adalah kata baku artinya tolak ukur yang dipakai patokan. ${ }^{8}$ Uraian tersebut mengatakan, bahwa perjanjian baku merupakan perjanjian yang sudah ditentukan atau ditetapkan dalam suatu perjanjian jual beli. Perjanjian baku dapat dikatakan sebagai tolak ukur sebagai patokan atau pedoman dalam melakukan perjanjian jual beli.

\footnotetext{
Az Nasution, 1995, Konsumen Dan Hukum, Tinjaun Sosial, Ekonomi, dan Hukum Pda Perlindungan Konsumen Indonesia, Pustaka Sinar Harapan, Jakarta,hlm. 44.

8 Abdulkadir Muhamad, 1986, Hukum Perjanjian, Alumni Bandung, hlm. 93.
}

Vol. 5, No. $2: 337$ - 352

http://ojs.unud.ac.id/index.php/jmhu

Menurut Pasal 1 ayat (10) Undang-Undang Nomor 8 Tahun 1999 menyatakan:

"Klausula baku adalah setiap aturan atau ketentuan dan syaratsyarat yang telah dipersiapkan dan ditetapkan terlebih dahulu secara sepihak oleh pelaku usaha yang dituangkan di dalam suatu dokumen dan/atau perjanjian yang mengikat dan wajib dipenuhi oleh konsumen"

Dari uraian Pasal tersebut dapat dikatakan, bahwa Klausula baku merupakan suatu aturan atau syaratsyarat ketentuan yang harus persiapkan terlebih dahulukedalam suatu dokumen yang sifatnya mengikat wajib dipenuhi oleh konsumen. Menurut Gunawan W dan Ahmad Y, mengatakan:

Perjanjian baku adalah suatu dokumen atau perjanjian yang dibuat oleh salah satu pihak yang "lebih dominan" dari pihak lainnya. Dikatakan bersifat" baku", karena baik perjanjian maupun klausula tersebut, tidak dapat dan tidak mungkin dinegosiasikan atau tawar menawar oleh pihak lainnya. ${ }^{9}$

Uraian tersebut mengatakan perjanjian baku merupakan suatu dokumen yang dibuat oleh salah satu pihak saja dan perjanjian tersebut tidak dapat dinegosiasikan atau ditawar oleh pihak lainnya.

Mariam Darus Badrulzaman mengatakan, bahwa Perjanjian Standard (baku) adalah perjanjian yang isinya dibakukan dan dituangkan dalam

Gunawan W dan Ahmad Y, 2000, Perlindungan Konsumen, Cet. 1, PT Gramedia Utama, Jakarta, hlm. 53. 
bentuk formulir. ${ }^{10}$ Dalam praktek perjanjian tumbuh sebagai perjanjian tertulis dalam bentuk formulir. Hal ini karena perbuatan-perbuatan hukum sejenis yang selalu terjadi berulangulang dan teratur melibatkan banyak orang, menimbulkan kebutuhan untuk mempersiapkan isi perjanjian itu terlebih dahulu dan kemudian dilakukan penyediaan setip saat jika diperlukan.

Dalam menggunakan perjanjian baku ini, tidak selamanya dipandang dari sisi negatifnya saja. Dalam hal ini perjanjian baku juga dipandang memiliki sisi positif. Sisi positifnya menurut Sidartha menyatakan, bahwa dibuatnya perjanjian baku itu bertujuan untuk memberikan kemudahan atau kepraktisan bagi para pihak yang bersangkutan. ${ }^{11}$ Beliau mengatakan, bahwa kemudahan dan kepraktisan mempunyai maksud yaitu berupa transaksi konsumen umumnya cepat, biaya penyusunan kontrak praktis, syarat-syarat konsumen umumnya telah tersusun, sehingga adanya penghematan energi bagi konsumen.

Menurut Pasal 1320 KUH Perdata menyebutkan, bahwa suatu perjanjian harus memenuhi empat unsur diantaranya yaitu:

1. Sepakat mereka yang eratmengikatkan dirinya,

\footnotetext{
10 Mariam Darus Badrulzaman,1981, Pembentukan Hukum Nasional dan Permasalahannya. Alumni Bandung, hlm. 68.

11 Sidartha, 2000, Hukum Perlindungan Konsumen Indonesia, PT Grasindo, Jakarta, hlm. 119.
}

2. Kecakapan untuk membuat suatu perikatan,

3. Suatu hal tertentu,

4. Suatu sebab yang halal.

Dalam perjanjian baku dianggap sah apabila telah memenuhi syaratsyarat baku yang ditentukan. Sahnya suatu perjanjian baku, apabila diperlakukannya syarat-syarat baku bagipara pihak yangmenginginkannya. AZ. Nasution mengatakan terdapat tiga cara berlakunya syarat-syarat baku diantaranya, yaitu:

1. Memuatnya dalam butir-butir perjanjian yang konsepnya telah dipersiapkan terlebih dahulu oleh salah satu pihak, biasanya oleh kalangan pengusaha, baik itu produsen, distributor, atau pedagang eceran produk bersangkutan itu. Pokoknya disediakan oleh si penyedia barang atau jasa yang ditawarkan pada orang banyak (perhatikan kontrak-kontrak jual beli atau beli sewa kendaraan bermotor, perumahan, alat-alat elektronik dan lain-lain.

2. Dengan memuatnya dalam carik-carik kertas baik berupa tabel, kwitansi, bon, tanda terima barang atau lain-lain.(perhatikan pada carik kertas /bon/atau tanda penyerahan barang dari toko, kedai, supermarket dan sebagainya).

3. Denganpembuatanpengumuman tentang tentang berlakunya syarat-syarat baku ditempat- 
tempat tertentu, seperti ditempattempat parkir atau di hotel/ penginapan dengan meletakkan atau menempelkan pengumuman itu di meja /di ruang penerimaan tamu atau duduk pada kamar yang disewakan. ${ }^{12}$

Berdasarkan pendapat beliau diatas, sahnya suatu perjanjian baku dapat dikatakan, apabila para pihak yang menginginkan perjanjian itu serta memenuhi ketentuan-ketentuan syarat-syarat baku degan jalan menandatangani persyaratan tersebut. Dengan diterima syarat-syarat baku itu, berarti telah terjadi persesuian kehendak antar pihak-pihak yang berjanji, dan syarat-syarat baku ini akan mempunyai kekuatan yang mengikat.

Perjanjian baku yang terdapat di masyarakat Mariam Darus Badrulzaman mengemukakan ada beberapa jenis perjanjian baku dapat dibedakan yaitu:

1. Perjanjian baku sepihak adalah perjanjian yang isinya ditentukan oleh pihak yang kuat kedudukannya dalam perjanjian itu. Pihak yang kuat di sini yakni pihak kreditur yang lazimnya mempunyai posisi yang kuat bila dibandingkan dengan pihak debitur.

12 E.H Hondios, 1999, Syarat-Syarat Baku Dalam Hukum Kontrak, termuat pada Compedium Hukum Belanda, Yayasan Kerjasama Ilmu Hukum Indonesia Belanda, S-Gravenhage 1978 hlm 151 Dikutip Dari Az Nasution, Perlindungan Konsumen Suatu Pengantar, cet 1, Daya Widya, Jakarta, hlm 101.
Vol. 5, No. $2: 337$ - 352

http://ojs.unud.ac.id/index.php/jmhu
2. Perjanjian baku yang ditetapkan olehpemerintahadalahperjanjian baku yang isinya ditentukan oleh pemerintah terhadap perbuatanperbuatan hukum tertentu, misalnya perjanjian yang mempunyai obyek hak atas tanah.

3. Perjanjian baku yang ditentukan di lingkungan notaris atau advokat adalah perjanjianperjanjian yang konsepnya sejak semula sudah disediakan untuk memenuhi permintaan dari anggota masyarakat yang minta bantuan notaris atau advokat yang bersangkutan. ${ }^{13}$

Seperti telah disebutkan diatas, beberapa jenis perjanjian baku ada yang disebut dengan perjanjian baku sepihak. Dalam hal ini diumpamakan seseorang yang ingin membeli sepeda motor dengan cara kredit, pada umumnya terlebih dahulu mereka menerima formulir yang berisikan syarat-syarat untuk melakukan kredit sepeda motor, dimana para konsumen harus memperhatikan syarat-syarat tersebut untuk mengajukan kredit ke perusahaan sepeda motor itu. Oleh sebab keinginan konsumen untuk memiliki sepeda motor, maka mereka menerima syarat-syarat yang ditentukan oleh pihak perusahaan. Apabila dalam hal ini ada beberapa pihak yang kurang menerima, namun

3 Mariam Darus Badrulzaman, 1980, Perjanjian Baku Perkembangannya di Indonesia, Alumni Bandung, hlm. 10. 
itu merupakan persyaratan yang harus dilakukan untuk mendapatkan barang yang mereka inginkan agar tidak ada unsur paksaan dalam melaksanakan perjanjian baku ini , sebaiknya para pembuat perjanjian atau pengusaha harus mengingatkan para konsumen akan adanya perjanjian baku tersebut.

Pada umumnya perjanjian baku terdapat pada bidang-bidang atau usaha pemberi jasa kepada masyarakat, maka dari itu perjanjian baku bersifat:

1. Pelayanan berkala

Sifat ini timbul karena hubungan hukum antara pengusaha dan konsumen tidk tetap.

2. Pemberi Kuasa

Adanya pemberian ini adalah karena konsumen telah memberikan kuasa atau kepercayaan kepada pengusaha untuk melakukan sesuatu, umpamanya kredit sepeda motor. Tentang pemberi kuasa ini sebagaimana dirumuskan dalam Pasal 1792 KUH Perdata , adalah "Suatu persetujuan atas suruhan pemberi kuasa dengan menggunakan kata " atas nama si pemberi kuasa". ${ }^{14}$

Hal tersebut dapat dikatakan, bahwa perjanjian baku umumnya mempunyai bidang-bidang sendiri, baik itu bersifat pelayanan berkala, dan pemberi kuasa, sehingga suatu

14 Priyono Prodjodikoro, 1981, Hukum Perdata Tentang Persetujuan-persetujuan Tertentu, Cet ke-VII, Sumur Bandung, hlm. 152. persetujuan tersebut menggunakan atas nama si pemberi kuasa.

Perlindungan konsumen memiliki istilah berkaitan dengan perlindungan hukum. ${ }^{15}$ Oleh sebab itu, perlindungan konsumen mengandung aspek hukum. Secara umum dikenal ada empat hak dasar konsumen yaitu:

1. Hak untuk mendapatkan keamanan (the right to safety)

2. Hak untuk mendapatkan informasi (the right to be informed)

3. Hak untuk memilih (the right to chosse)

4. Hak untuk didengar (the right to be hard).

Selanjutnya suatu perjanjian baku pada dasarnya mengandung sifat-sifat yang banyak menimbulkan kerugian pada pihak konsumen, padahal sebenarnya para konsumen harus memperoleh hak-hak mereka yang wajib didapatkannya. Berkaitan dengan adanya suatu perjanjian baku ini, maka pemerintah Indonesia merasa perlu membuat suatu ketentuan hukum yang dapat melindungi kepentingan para konsumen, sehingga terbentuklah Undang-Undang Nomor 8 Tahun 1999. Hak konsumen diatur dalam Pasal 4, bagian pertama dan kewajiban konsumen diatur dalam Pasal 5, bagian kedua, Bab III Undang-Undang Nomor 8 Tahun 1999 tentang Perlindungan Konsumen, pada Pasal tersebut menyatakan, hak-hak

$15 \quad$ Sidartha, Op Cit, hlm. 16. 
yang diberikan berupa kenyamanan, keamanan, dan keselamatan, memilih, mendapatkan informasi, mendengar keluhan, mendapatkan perlindungan, mendapatkan pendidikan, memperoleh pelayanan yang baik pada konsumen, kewajiban konsumen mengikuti petunjuk prosedur pemakaian suatu barang, beritikad baik dalam bertransaksi, mengikuti upaya penyelesaian sengketa.

Kemudian pada bagian kedua, Bab III, Undang-Undang Nomor 8 Tahun 1999 tentang Perlindungan Konsumen, hak pengusaha diatur dalam Pasal 6 dan kewajiban pengusaha diatur dalam Pasal 7.

Adapun hak pengusaha yaitu, hak menerima pembayaran, hak untuk mendapatkan perlindungan hukum, dan hak untuk mendapatkan pembelaan diri, sedangkan kewajibannya yaitu, beritikad baik dalam melakukan kegiatan, memberikan informasi yang benar, melayani konsumen dengan baik, dan memberi kompensasi ganti rugi

Ketentuan Pasal 6 dan Pasal 7 Undang-Undang Nomor 8 Tahun 1999 in sebagai hak dan kewajiban pelaku usaha yang merupakan intimoni (memiliki makna sama) dalam hukum, sehingga kewajiban pelaku usaha dapat dilihat sebagai hak konsumen.

Dari hak-hak tersebut di atas, ada juga hak untuk dilindungi dari akibat, negatif persaingan curang (Unfair Competition). Dengan uraian tersebut diatas dapat dikatakan secara yuridis (hukum) perlindungan konsumen memiliki beberapa aspek, antara lain:

1. Aspek hukum perlindungan konsumen keperdataan, mencakup hukum perikatan dan hukum kebendaan;

2. Aspek hukum perlindungan konsumen pidana;

3. Aspek hukum perlindungan konsumen tata negara dan

4. Aspek hukum perlindungan konsumen tradisional.

Dengan demikian dapat
disimpulkan, bahwa aspek
perlindungan konsumen terkandung
dalam perjanjian baku adalah sebagai
berikut: 1. Aspek hukum perdata, meliputi perikatan dan hukum kebendaan.

2. Aspek hukum publik, meliputi hukum pidana dan hukum administrasi negara.

\section{Ad 1. Aspek Hukum Perdata}

Salah satu asas hukum yang dianut oleh hukum perjanjian adalah "asas kebebasan berkontrak" yang berarti setiap orang bebas mengadakan suatu perjanjian yang memuat syaratsyarat perjanjian macam apapun, sepanjang perjanjian dibuat secara sah dan beritikad baik, serta tidak melanggar ketertiban umum dan kesusilaan ( Pasal 1320 Jo 1338 ). Perjanjian tersebut berlaku sebagai undang-undang bagi para pihak. Buku ketiga tentang perikatan Kitab Undang-Undang Hukum Perdata pada 
umumnya memuat tentang kaidahkaidah hukum yang berkenaan dengan transaksi konsumen (hubungan hukum konsumen). Salah satunya hubungan konsumen yaitu, jual beli kredit sepeda motor diantaranya, Honda dan Yamaha yang berlokasi di lingkungan wilayah Denpasar terjadi dengan menggunakan syarat-syarat baku (selanjutnya disebut perjanjian baku atau standard contract) adalah perjanjian yang syarat-syaratnya telah dipersiapkan terlebih dahulu oleh pihak pelaku usaha. Perlindungan terhadap konsumen yang diberikan oleh pemerintah Indonesia melalui ketentuan Undang-Undang Nomor 8 Tahun 1999, khususnya Bab V, ketentuan pencantuman klausula baku, Pasal 18 menyebutkan, bahwa pelaku usaha dalam melakukan transaksi jual beli kredit terhadap konsumen harus memperhatikan ketentuan-ketentuan yang tertuang dalam Undang-Undang Nomor 8 Tahun 1999 yang pada prinsipnya bermaksud atau bertujuan melindungi terhadap para konsumen.

Ad 2. Aspek Hukum Publik

Dengan aspek hukum publik, dimaksudkan segi-segi hukum publik yang menjadi sumber dan/ atau para lingkungan konsumen dan/ atau perlindungan konsumen. Segi hukum pidana yang berkaitan dengan perlindungan konsumen memberikan pengaruh pada perlindungan konsumen, akibat tindak pidana dilakukan seseorang (pihak pelaku usaha dan konsumen), maka pihak konsumen secara materiil berhak mengajukan perkara ganti rugi terhadap pelaku tidak pidana tersebut. Secara administrasi bertugas mengatur penataan dan kendali pemerintah terhadap berbagai kegiatan warga dalam kehidupan di masyarakat nasional maupun internasional, seperti melalui pemberian izin (lisensi) mengadakan perancangan ataupun pemberian subsidi, termasuk juga pemerintah melakukan pembinaan atau pengawasan terhadap aktivitas warga masyarakat publik.

\subsection{Perjanjian Baku Dalam Jual Beli Kredit Sepeda Motor}

Alat transportasi sangat dibutuhkan oleh masyarakat untuk menjalankan aktivitasnya. Alat transportasi yang dimaksud di sini adalah sepeda motor. Supaya memilki sepeda motor, mereka harus datang keperusahaan sepeda motor untuk melihat merek apa yang mereka inginkan. Setelah memperoleh sepeda motor kemudian mereka mengadakan suatu transaksi jual beli. Menurut Subekti mengatakan:

Jual beli adalah suatu perjanjian yang bertimbal balik dalam mana piak yang satu (si penjual) berjanji untuk menyerahkan ha milik atas suatu barang. Sedang pihak yang lainnya (si pembeli) berjanji untuk membayar harga yang terdiri atas sejumblah uang sebagai imbalan dan perolehan hak milik tersebut. ${ }^{16}$

Selain melakukan transaksi jual beli secara tunaijuga ada menggunakan

\footnotetext{
16 Subekti, 1995, Aneka Perjanjian, Citra Aditya, Jakarta, hlm. 1.
} 
transaksi jual beli secara kredit. Dalam hal ini pihak konsumen dan pelaku usaha sebelum melakukan transaksi jual beli, mereka terlebih dahulu harus mengadakan suatu perjanjian, karena perjanjian tersebut memberikan kepastian dalam jual beli. Suatu perjanjian sah apabila terpenuhinya empat syarat yang terdapat dalam Pasal 1320 KUH Perdata. Dalam suatu perjanjian dikenal dengan adanya perjanjian baku. Secara formal dasar berlakunya perjanjian terlihat dalam buku III, Pasal 1338 KUH Perdata yang menyatakan:

"Semua perjanjian yang dibuat secara sah berlaku sebagai Undang-Undang bagi mereka yang membuatnya".

Sedangkan perjanjian baku menurut Pasal 1 ayat (10) UndangUndang Nomor 8 Tahun 1999, menyatakan:

"Klausula baku adalah setiap aturan atau ketentuan dan syaratsyarat yang telah disediakan dan ditetapkan terlebih dahulu secara sepihak oleh pelaku usaha yang dituangkan kedalam suatu dokumen /atau perjanjian yang mengikat dan wajib dipenuhi oleh konsumen".

Dalam hal ini jual beli kredit sepeda motor, untuk memperoleh sepeda motor secara kredit pihak konsumen terlebih dahulu menanyakan syarat-syarat apa yang harus dipenuhi. Dalam jual beli kredit sepeda motor syarat-syarat baku sudah dicantumkan dalam persyaratan kredit. Syaratsyarat baku tersebut harus jelas dapat
Vol. 5, No. 2 : 337 - 352

http://ojs.unud.ac.id/index.php/jmhu dimengerti oleh pihak konsumen. Dalam Pasal 18 ayat (2), Bab V Undang-Undang Nomor 8 Tahun 1999, diberlakukan larangan bagi:

"Pelaku usaha dagang mencantumkanklausulabaku,yang letak atau bentuknya sulit terlihat atau tidak dapat dibaca secara jelas atau yang pengungkapannya sulit dimengerti”.

Jadi dari ketentuan Pasal tersebut diatas, pelaku usaha dalam membuat suatu perjanjian harus menepati butirbutir perjanjian pada formulir secara jelas dan teliti agar tidak terjadi kesalahan dalam jual beli kredit sepeda motor. Dari data-data yang diperoleh pada perusahaan Suzuki, Yamaha, dan Honda sudah jelas mencantumkan syarat-syarat baku dalam jual beli kredit sepeda motor. Dari masing-masing diatas, syaratsyarat baku dalam jual beli kredit sepeda motor disediakan oleh pelaku usaha (pihak konsumen). Syaratsyarat baku tersebut sudah jelas serta dimengerti oleh konsumen baik dalam pencantuman harga ketentuan kredit maupun kelengkapan administrasi. Tujuan penyediaan syarat-syarat baku oleh pelaku usaha (pihak perusahaan) yaitu untuk memudahkan konsumen di dalam mengadakan transaksi jual beli kredit sepeda motor. Pasal 18 ayat (4). Bab V Undang-Undang Nomor 8 Tahun 1999 menyatakan, bahwa:

"Pelaku usaha wajib menyesuaikan klausula baku yang bertentangan dengan Undang-Undang ini” 
Dari Pasal tersebut diatas perjanjian baku dapat digunakan tetapi harus sesuai kesepakatan kedua belah pihak serta keinginan dari masing-masing pihak dan tidak keluar dari aturan-aturan yang ada - Dalam perjanjian baku, dimana pelaksanaannya pelaku usaha dan konsumen harus melaksanakan hak dan kewajibannya.

Perjanjian baku merupakan suatu perjanjian yang dibuat sepihak oleh pelaku usaha, dimana perjanjian tersebut harus disepakati oleh pihak konsumen. Dari sahnya suatu perjanjian akan menimbulkan suatu akibat hukum yang mengikat bagi kedua belah pihak yang membuatnya sera menimbulkan hak dan kewajiban bagi kedua belah pihak. Dalam jual beli kredit sepeda motor, pihak pelaku usaha dan pihak konsumen terlebih dahulu mengikatkan dirinya, dimana pihak pelaku usaha menunjukkan kepada konsumen menjadi syaratsyarat kredit sedangkan pihak konsumen melihat dan memperhatikan syarat-syarat tersebut, masing-masing pihak disini tidak dapat berbuat bebas dalam melakukan suatu tindakantindakan. Mereka harus mentaati dan mematuhi perjanjian yang mereka buat. Apabila pihak konsumen lalai melaksanakan kewajibannya, maka pelaku usaha dapat memberi sanksi kepada konsumen berupa denda. Pihak konsumen juga mempunyai hak yaitu hak untuk menerima barang yang utuh dari pelaku usaha. Sedangkan kewajiban dari pelaku usaha wajib memberikan pelayanan yang terbaik. Apabila pihak konsumen terlambat membayar dari waktu yang ditentukan oleh pihak Bank, maka konsumen akan dikenakan denda jika hal tersebut tidak diindahkan oleh pihak konsumen.

Pada hakikatnya perjanjian dilakukan oleh manusia berdasarkan kesepakatan kedua belah pihak sebagaimana dalam aktivitasnya mereka bebas dalam melakukan upaya perjanjian baik itu dalam bentuk lisan maupun tulisan. Perjanjian dalam bentuk tertulis merupakan perjanjian standar atau baku. Pelaksanaan perjanjian baku dalam jual beli kredit sepeda motor sepenuhnya yang diatur oleh pihak yang berkepentingan. Dalam hal ini salah satunya pihak perusahaan sepeda motor atau dealer itu sendiri. Pada dasarnya syaratsyarat memperoleh kredit sepeda motor sepeda motor antara dealer yang satu dengan dealer yang lainnya baik itu Suzuki, Yamaha, dan Honda adalah sama, seperti fotocopy KTP pemohon, fotocopy kartu keluarga, fotocopy daftar gaji terakhir, dan data lainnya jika diperlukan, namun dalam pelaksanaannya biasanya memiliki sedikit perbedaan. Dimana bunga yang dibebankan pihak dealer kepada konsumen tergantung dari keinginan serta kemampuan pihak konsumen itu sendiri. Berkaitan dengan pembayaran bunga menurun maupun menetap diserahkan pada pihak Bank. Pihak Bank akan menetapkan berapa bunga 
yang dibebankan kepada pihak konsumen. Apabila pihak konsumen terlambat membayar dari waktu yang ditentukan oleh pihak Bank, maka pihak konsumen dikenakan denda. Jika hal tersebut tidak diindahkan oleh pihak konsumen, maka dari itu pihak Bank akan mengambil tindakan-tindakan yang efektif. Tindakan-tindakan yang diambil oleh pihak Bank biasanya melalui surat peringatan terlebih dahulu. Surat peringatan pertama berlaku 2 minggu. Jika peringatan pertama, kedua, dan ketiga tidak dipatuhi, maka pihak Bank aksan menunjuk salah satu karyawan dari pihak dealer agar mendatangi pihak konsumen untuk memperoleh penjelasan mengenai keterlambatannya membayar kredit, maka pihak Bank akan memberikan pihak konsumen untuk membuat surat pernyataan. Apabila surat pernyataan yang dibuat ole pihak konsumen juga tidak dipenuhi, maka karyawan ditunjuk oleh pihak Bank menanyakan kembali mengapa tidak dibayarnya kredit tersebut. Biasanya jalan yang ditempuh pihak Bank yaitu membantu pihak konsumen yang bersangkutan untuk menjual sepeda motornya yang sudah duiambil melalui kredit. Sesudah sepeda motor itu terjual, maka uang hasil penjualan akan dipakai menutupi pembayaran dalam kredit yang masih ditunggak olehpihak konsumen kepada pihak Bank dan sisa dari pembayaran kredit sepeda motor akan dikembalikan oleh pihak konsumen. Jadi disini jelas, bahwa dalam hal kredit sepada motor, pihak dealer menyerahkan sepenuhnya kepada pihak Bank yang dipercaya oleh masing-masing dealer untuk bekerja sama antara dealer yang satu dengan yang lain berbeda. Menurut Pak Dewa Astina, pimpinan pada perusahaan dealer Suzuki Indo Perkasa. ${ }^{17}$ Mengatakan Bank yang dipercaya untuk diajak bekerja sama yaitu Bank Putra Aken. Dalam pelaksanaannya piak dealer tidak menerima atau menangani pembayaran kredit. Pihak dealer langsung memberi memberitahukan pihak konsumen untuk datang ke Bank yang bersangkutan untuk membayar kredit. Menurut Ibu Sri, bagian perkreditan pada dealer Yamaha Niaga Motor. $^{18}$ Mengatakan Bank yang dipercaya untuk diajak bekerja sama adalah Bank Perkreditan Rakyat Kertiawa Dananiaga. Dimana dalam pelaksanaan pihak dealer terlebih dahulu menangani pembayaran kredit dari jam kerja sampai sore. Kemudian sorenya dari pihak Bank datang untuk mengambil pembayaran kredit dari pihak konsumen di dealer Yamaha tersebut untuk selanjutnya ditangani oleh pihak Bank. Selanjutnya menurut ibu Monik, bagian perkreditan, pada dealer Honda Made Ferry Motor, ${ }^{19}$ mengatakan Bankyang dipercayauntuk diajak bekerja sama yaitu Bank Sinar Harapan Bali. Dalam pelaksanaannya dealer Honda Made Ferry Motor

\footnotetext{
Wawancara 3 Januari 2002

Wawncara 3 J anuari 2002

Wawancara 4 Januari 2002
} 
sama dengan Suzuki Indo Perkasa. Di sini pelaksanaan pengambilan kredit dari masing-masing Bank pada pihak konsumen ada yang sama ada yang berbeda, yang berbeda di sini adalah dealer Yamaha Niaga Motor. Pihak dealer hanya melayani pembelian secara tunai saja. Dalam pelaksanaan jual beli kredit sepada motor ditinjau dari Undang-Undang Nomor 8 Tahun 1999 diatur dalam pasal 47, bagian kedua menyebutkan:

"Penyelesaian sengketa konsumen diluar pengadilan untuk mencapai kesepakatan mengenai tindakan tertentu untuk menjamin tidak akan terjadi kembali atau tidak"

Pasal 47 Undang-Undang Nomor 8 Tahun 1999 diatas menekankan, bahwa penyelesaian sengketa antara pelaku usaha dan konsumen ditempuh dengan jalan damai atau melalui kekeluargaan, karena dengan jalan damai para pelaku usaha dalam menyelesaikan sengketa tidak perlu melalui jalan pengadilan.

\section{PENUTUP}

\subsection{Simpulan}

Dari uraian-uraian tersebut di atas, akhirnya tiba pada kesimpulan sebagai berikut:

1. Perlindungan hukum terhadap konsumen atau debitur dalam jual beli kredit sepeda motor berpedoman pada UndangUndang Nomor 8 Tahun 1999, yang mengatur tentang hak dan kewajiban konsumen, untuk mengimbangi hak dan kewajiban konsumen Undang-Undang Perlindungan Konsumen juga memberlakukan hak dan kewajiban bagi pelaku usaha. Sehubungan dengan hal tersebut, maka pelaku usaha harus memperhatikan dengan jelas dan teliti dalam membuat suatu perjanjian baku jual beli kredit sepeda motor yang diatur dalam Pasal 12 ayat 2 dan 4.

2. Penerapan perjanjian baku dalam jual beli kredit sepeda motor Harus sesuai dengan UndangUndang Nomor 8 Tahun 1999. Berdasarkan Undang-Undang tersebut diatas suatu perjanjian yang dibuat oleh kedua belah pihak harus dipatuhi serta melaksanakan isi dari perjanjian tersebut. Apabila konsumen melakukan pelanggaran terhadap isi dari perjanjian itu, seperti keterlambatan untuk membayar kredit, maka konsumen akan dikenakan sanksi berupa denda, kalau selama waktu yang telah ditentukan konsumen tidak membayar kredit beserta dendanya, maka pihak pelaku usaha akan mengambil tindakan-tindakan yang pertama memberikan surat peringatan kepada konsumen, baik itu surat peringatan pertama, kedua, dan ketiga dengan jangka waktu masing-masing dua minggu. Bila ketiga peringatan tidak 
diindahkan oleh konsumen, maka pelaku usaha mengambil tindakan selanjutnya yang lebih efektif, dengan mendatangipihak konsumen untuk menyelesaikan masalah tersebut. Dalam hal ini sesuai ketentuan yang diatur dalam Pasal 47 bagian dua Undang-Undang Nomor 8 Tahun 1999 yang menekankan, bahwa penyelesaian sengketa antara pelaku usaha dengan konsumen ditempuh dengan jalan damai atau melalui kekeluargaan.

\subsection{Saran}

1. Pelaku usaha membuat suatu perjanjian baku dalam jual beli kredit sepeda motor, harus sesuai denganperjanjianpadaumumnya yang diatur dalam KUH Perdata dan perjanjian baku khususnya yang diatur dalam UndangUndang Nomor 8 Tahun 1999. Di dalam Undang-Undang tersebut diatas konsumen diberikan hak seperti mendapatkan informasi yang benar dari pelaku usaha dan pelaku usaha berkewajiban untuk memberikan informasi yang benar kepada konsumen serta memperhatikan lebih teliti dalam mencantumkan butirbutir perjanjian kedalam bentuk formulir atau blangko. Jadi dalam hal ini tidak akan merugikan kedua belah pihak, baik itu konsumen maupun pelaku usaha untuk berjanji.
2. Untuk menyelesaikan masalah yang terjadi dalam pelaksanaan jual beli kredit sepeda motor, seperti konsumen terlambat membayar kredit, pelaku usaha hendaknya memberikan kemudahan-kemudahan, kebijaksanaan serta memberikan perpanjangan waktu lebih kepada konsumenuntukuntukmemenuhi kewajibannya membayar kredit dan pelaku usaha hendaknya tidak begitu membebani dengan denda terlalu tinggi atau dengan cara yang berbentuk paksaan, seperti dengan mengambil sepada motor tersebut tanpa ada kompromiterlebihdahulukepada konsumen. Hendaknya dalam penyelesaian ini disesuaikan dengan Pasal 47, bagian dua, Undang-Undang Nomor 8 Tahun 1999, diselesaikan dengan jalan damai dan secara kekeluargaan.

\section{DAFTAR PUSTAKA}

Badrulzaman Darus Mariam, 1980, Perjanjian Baku Perkembanganya di Indonesia, Alumni Bandung.

Badrulzaman Darus Mariam, 1981, Pembentukan Hukum Nasional dan Permasalahannya. Alumni Bandung.

Gunawan W dan Ahmad Y, 2000, Perlindungan Konsumen, Cet, 1, PT. Gramedia Utama, Jakarta.

Hondios E.H, 1999, Syarat-Syarat Baku Dalam Hukum Kontrak, 
termuatpadaCompediumHukum Belanda, Yayasan Kerjasama Ilmu Hukum Indonesia Belanda, Yayasan Kerjasama Ilmu Hukum Indonesia Belanda, S-Gravenhage 1978 hlm 151 Dikutip dari $\mathrm{Az}$ Nasution, Perlindungan Konsumen Suatu Pengantar, Cet 1, Daya Widya, Jakarta.

Muhamad Abdulkadir, 1986, Hukum Perjanjian, Alumni Bandung.

Nasution Az, 1995, Konsumen dan Hukum, Tinjauan Sosial, Ekonomi, dan Hukum pada Perlindungan Konsumen Indonesia. Pustaka Sinar Harapan, Jakarta.

Prodjodikoro Priyono, 1981, Hukum Perdata Tentang PersetujuanPersetujuan Tertentu, Cet keVII, Sumur Bandung.

Program Studi Magister (S2) Ilmu Hukum Program Pasca Sarjana Universitas Udayana, 2013, Pedoman Penulisan Usulan Penelitian Tesis dan Penulisan Program Studi Magister (S2) Ilmu Hukum.

Salim. H. dan Erlies Septiana Nurbani, 2013, Penerapan Teori Hukum pada Penelitian Tesis dan Disertasi, PT. Raja Grafindo Persada, Jakarta.

Sidartha, 2000, Hukum Perlindungan Konsumen Indonesia, PT. Grasindo, Jakarta.

Subekti, 1995, Aneka Perjanjian, Citra Aditya, Jakarta.
Subekti, 1979, Hukum Perjanjian, Cet ke-IV, PT. Intermasa, Jakarta.

Wawancara 2 April 2016

Wawancara 5 April 2016

Wawancara 7 April 2016

\section{Perundang-Undangan :}

1. Kitab Undang-Undang Hukum Perdata.

2. Undang-Undang No. 8 Tahun 1999 tentang Perlindungan Konsumen. 